\title{
UJI ANGKA LEMPENG TOTAL, ANGKA KAPANG KHAMIR, DAN Most Probable Number (MPN) Coliform TERHADAP SAYAP LALAT RUMAH (Musca Domestica)
}

\author{
Ulfa Nur Maa'idah $^{1}$, Charlis Palupi ${ }^{2}$, Lina Sulis Setyawati ${ }^{3}$ \\ Akafarma Sunan Giri Ponorogo, Jl. Batoro Katong 32 Ponorogo \\ Email: ${ }^{1)}$ ulfa.akafarma@gmail.com , ${ }^{2)}$ Palupicharlis@ gmail.com , ${ }^{3)}$ hinasuliss97@ gmail.com
}

\begin{abstract}
ABSTRAK
Latar belakang: Lalat rumah (Musca Domestica) merupakan hewan yang membawa bakteri tertentu contohnya Escherichia coli dan Salmonella. Biasanya bakteri ini terdapat di bagian tubuh lalat rumah yaitu pada kaki, badan, dan sayap. Tujuan: Untuk mengetahui perbedaan jumlah mikroba pada aquadest steril yang telah ditambahkan sayap kanan lalat rumah, sayap kiri lalat rumah dan sayap kanan dan kiri lalat rumah. Metode: Populasi dalam penelitian ini adalah lalat rumah (Musca Domestica), sampel sayap lalat rumah diambil dengan teknik Simple Random Sampling selanjutnya dilakukan uji ALT, AKK, dan MPN Coliform, untuk mengetahui perbedaan jumlah mikroba pada masing-masing sayap lalat rumah Hasil: Pengujian jumlah ALT sampel I (Sayap kiri), $93 \times 10^{-1}$ koloni/ml, sampel II (Sayap kanan), 87,5 x 10 ${ }^{-1}$ koloni/ml, dan sampel III (Sayap kanan kiri), 246,5 x $10^{-2} \mathrm{koloni} / \mathrm{ml}$, pengujian AKK sampel I (Sayap kiri), 47,5 x 10 koloni/ml, sampel II (Sayap kanan), $6,75 \times 10^{1} \mathrm{koloni} / \mathrm{ml}$, dan sampel III (Sayap kanan kiri), 49,75 x $10^{1} \mathrm{koloni} / \mathrm{ml}$. Pengujian MPN Coliform sampel I (Sayap kiri), >2400 MPN/100ml, sampel II (Sayap kanan), >2400 MPN/100ml, Sampel III (Sayap kanan kiri), >2400 MPN/100ml. Simpulan dan Saran: Hasil penelitian menujukkan bahwa sayap kanan mempunyai jumlah mikroba lebih sedikit dibandingkan dengan sayap kiri, dan sayap kanan kiri. Sehingga perlu dilakukan pengujian lebih lanjut untuk mengetahui bakteri apa yang terdapat pada masing-masing sayap lalat rumah (Musca Donestica) sehingga mempengaruhi perbedaan jumlah mikroba pada masing-masing sayap tersebut.
\end{abstract}

Kata Kunci: Mikroorganisme, Sayap Lalat Rumah, Uji Cemaran Mikroba

\begin{abstract}
Background: House flies (Musca Domestica) are animals that carry certain bacteria, for example Escherichia coli and Salmonella. Usually these bacteria are found on the body parts of the house fly, namely on the legs, body and wings. Purpose: To determine the difference in the number of microbes in sterile aquadest which has been added to the right wing of the house fly, the left wing of the house fly and the right and left wings of the house fly. Methods: The population in this study were house flies (Musca Domestica), samples of house fly wings were taken using the simple random sampling technique. Then the ALT, AKK, and MPN Coliform tests were carried out, to determine the difference in the number of microbes on each of the house fly wings. Results: Tests for the number of ALT samples I (left wing), $93 \times 10^{-1}$ colony / ml, sample II (right wing), $87.5 \times 10^{-1}$ colony / ml, and sample III (right wing left), $246.5 \times 10^{-2}$ colonies / ml, AKK test sample I (left wing), $47.5 \times 10^{-1}$ colony / $\mathrm{ml}$, sample II (right wing), $6.75 \times 10^{-1}$ colony / $\mathrm{ml}$, and sample III (right wing left), $49.75 \times$ $10^{-1}$ colony / ml. MPN Coliform Testingsample I (Left wing), > $2400 \mathrm{MPN} / 100 \mathrm{ml}$, sample II (Right wing),> 2400 MPN / 100ml, Sample III (right wing left),> 2400 MPN / 100ml. Conclusions and Recommendations: The results showed that the right wing has a number of microbes is less than the left-wing and right wing left. So it is necessary to do further testing to find out what bacteria are present on each wing of the house fly (Musca Donestica) so that it affects the differences in the number of microbes on each of these wings.
\end{abstract}

Keywords: Microorganisme, House Fly Wings , Microbial Contamination Test 


\section{Jurnal MEDFARM: Farmasi dan Kesehatan}

Vol. 9, No.1, Januari 2020, hal 1-7

e-ISSN : 2715-9957

\section{PENDAHULUAN}

Lalat rumah merupakan hewan yang membawa bakteri tertentu contohnya Escherichia coli dan Salmonella. Biasanya bakteri ini terdapat di bagian tubuh lalat rumah yaitu pada kaki, badan, dan sayap. Apabila suatu makanan atau minuman yang terkontaminasi oleh bakteri Escherichia coli dapat menyebabkan penyakit diare. Sedangkan Bakteri Salmonella dapat menyebabkan penyakit Salmonellosis di mana keadaan orang yang terinfeksi bakteri ini mengalami diare, demam, muntah dan sakit perut. (Safitri et al., 2017).

Sejauh ini masyarakat menilai lalat (Musca domestica) hanya sebagai hewan pembawa penyakit. Apabila lalat masuk dalam sesuatu minuman banyak orang yang beranggapan bahwa minuman tersebut sudah tidak dapat dikonsumsi. Namun dalam suatu hadist Al-Bukhary Muslim, menjelaskan bahwa Nabi Muhammad SAW pernah bersabda:

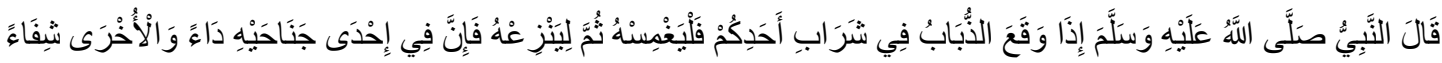
Yang artinya : "Apabila seekor lalat hinggap di tempat minum salah seorang dari kalian, hendaknya ia mencelupkan ke dalam minuman tersebut, kemudian membuangnya, karena pada salah satu sayapnya terdapat penyakit dan pada sayap lainnya terdapat penawarnya." (Sahih al-Bukhary No. 3073).

Allah SWT memberikan lalat kemampuan untuk membawa kuman pada salah satu sayapnya dan obat penawar pada sayap yang lain. Jika hal itu tidak terjadi, spesies lalat saat ini sudah punah akibat terkena kuman pada tubuh lalat itu sendiri. Namun sampai saat ini lalat masih ada di bumu dengan jumlah lebih dari 87.000 spesies. Berdasarkan hadist tersebut tujuan penelitian ini adah untuk mengetahui perbedaan jumlah mikroba yang terdapat pada masing-masing sayap lalat rumah (Musca Domestica) menggunakan metode Angka Lempeng Total, Angka Kapang Khamir, dan Most Probable Number (MPN) Coliform.

\section{METODOLOGI PENELITIAN}

Penelitian ini dilaksanakan di Laboratorium Akafarma Sunan Giri. Sampel dalam penelitian yaitu Aquadest Steril yang telah ditambahkan sayap lalat rumah (Musca Domestica). Lalat diperoleh menggunakan teknik pengumpulan data Sample Random Sampling. Kemudian dilakukan uji cemaran mikroba Angka Lempeng Total, Angka Kapang Khamir, dan Most Probable Number (MPN) Coliform untuk mengetahui jumlah perbedaan mikroba pada msing-masing sampel.

\section{Alat dan Bahan}

Alat-alat yang digunakan antara lain: Cawan petri, erlenmeyer, pipet volume, batang pengaduk, timbangan, tabung reaksi, tabung durham, rak tabung, autoclave, penjepit kayu, transpipet, beaker glass, pipet tetes, kaca arloji, jarum ose, lampu spirtus, inkas, inkubator, oven, kertas perkamen, kapas. 


\section{Jurnal MEDFARM: Farmasi dan Kesehatan}

Vol. 9, No.1, Januari 2020, hal 1-7

e-ISSN : 2715-9957

Bahan-bahan yang digunakan antara lain: sayap lalat rumah (Musca Domestica), aquadest steril, alkohol $95 \%$, pepeton cair 0,1\%, media Nutrient Agar, media Sabauroud Glucose Agar, media Lactoca Broth, media Brillliant Green Lactose Bile Broth, spirtus, formalin.

\section{Pengumpulan Lalat Rumah (Musca Domestica)}

Jumlah Lalat Rumah (Musca Domestica) sebanyak 14 ekor, diambil 7 sayap kanan, 7 sayap kiri, dan 14 untuk sayap kanan dan kiri. Masing-masing sayap diambil menggunakan forsep steril.

\section{Preparasi Ekstrak Sayap Lalat}

Setiap 7 sayap kanan, 7 sayap kiri, dan 14 untuk sayap kanan dan kiri di masukkan ke dalam aquadest steril $50 \mathrm{ml}$ selama 15 menit. Setelah 15 menit masing-masing sayap lalat di keluarkan dan ekstrak sayap lalat siap untuk di uji ALT, AKK dan MPN Coliform.

\section{Uji Angka Lempeng Total}

Angka lempeng total adalah metode yang digunakan untuk menghitung jumlah bakteri aerob mesofil dalam tiap $1 \mathrm{ml}$ sampel yang akan diperiksa. Media yang digunakan dalam penelitian ini yaitu media Nutriant Agar. Penentuan nilai Angka Lempeng Total dibuat pengenceran $1 \times 10^{-5}$. Langkah pertama yaitu mengambil $10 \mathrm{ml}$ sampel ekstrak sayap lalat di masukkan ke dalam erlenmeyer yang telah terisi pepton $90 \mathrm{ml}$ dan itu menjadi pengenceran $10^{-1}$, selanjutnya dari pengenceran pertama diambil $1 \mathrm{ml}$ sampel di masukkan ke dalam tabung reaksi yang telah terisi $9 \mathrm{ml}$ pepton dan itu menjadi pengenceran $10^{-2}$, dari pengenceran kedua diambil diambil $1 \mathrm{ml}$ sampel di masukkan ke dalam tabung reaksi yang telah terisi $9 \mathrm{ml}$ pepton dan itu menjadi pengenceran $10^{-3}$, dari pengenceran ketiga diambil $1 \mathrm{ml}$ sampel dari pengenceran pertama di masukkan ke dalam tabung reaksi yang telah terisi $9 \mathrm{ml}$ pepton dan itu menjadi pengenceran $10^{-4}$, dari pengenceran ke empat diambil $1 \mathrm{ml}$ sampel dari pengenceran pertama di masukkan ke dalam tabung reaksi yang telah terisi $9 \mathrm{ml}$ pepton dan itu menjadi pengenceran $10^{-5}$, selanjutnya dari masing-masing pengenceran diambil $1 \mathrm{ml}$ di masukkan ke dalam cawan petri yang telah terisi media Nutriant Agar dan dikakukan secara duplo. Setelah media padat selanjutya di inkubasi dengan suhu $35-37{ }^{\circ} \mathrm{C}$ selama $24-48$ jam . Kemudian dihitung koloni yang didapat (BPOM, 2008).

\section{Uji Angka Kapang Khamir}

Angka Kapang Khamir adalah metode yang digunakan untuk menetapkan angka kapang atau khamir dalam makanan dan minuman (BPOM, 2006). Penentuan nilai Angka Kapang Khamir dibuat pengenceran $1 \times 10^{-2}$. Langkah pertama yaitu mengambil $10 \mathrm{ml}$ sampel ekstrak sayap lalat di masukkan ke dalam erlenmeyer yang telah terisi pepton $90 \mathrm{ml}$ dan itu menjadi pengenceran $10^{-1}$, selanjutnya dari pengenceran pertama diambil $1 \mathrm{ml}$ sampel di masukkan ke dalam tabung reaksi yang telah terisi $9 \mathrm{ml}$ pepton dan itu menjadi pengenceran $10^{-2}$, selanjutnya dari masing-masing pengenceran diambil $1 \mathrm{ml}$ di masukkan ke dalam cawan petri yang telah terisi media Nutriant Agar dan dikakukan secara duplo. Setelah median padat selanjutnya diinkubasi dengan suhu $20-25{ }^{\circ} \mathrm{C}$ selama 3-5 hari. Kemudian hitung koloni yang didapat (Lay, 1994). 


\section{Jurnal MEDFARM: Farmasi dan Kesehatan}

Vol. 9, No.1, Januari 2020, hal 1-7

e-ISSN : 2715-9957

\section{Uji Most Probable Number (MPN) Coliform}

MPN Coliform adalah metode yang digunakan untuk menghitung jumlah bakteri khususnya untuk mendeteksi adanya bakteri Coliform ( BPOM, 2006). Hasil positif adanya bakteri Coliform dapat ditentukan dari terbentuknya asam dan gas yang dapat dilihat dari kekeruhan medium laktosa dan keberadaan gelembung udara. Asam yang terbentuk disebabkan oleh fermentasi laktosa oleh bakteri golongan koli, sedangkan jumlah tabung yang menunjukkan adanya gas yang terbentuk di dalamnya, harus sesuai dengan tabel MPN yang telah ditetapkan (Fardiaz, 2002).

Penentuan nilai MPN Coliform dilakukan dengan uji praduga (Presumtive test) dengan prosedur kerja menyiapkan 9 tabung reaksi yang telah $10 \mathrm{ml}$ media Lactose Broth yang dilengkapi tabung durham terbailk. Selanjutnya dibagi mejadi 3 kelompok. Kelompok I tabung berisi $10 \mathrm{ml}$ media Lactose Broth ditambah $10 \mathrm{ml}$ sampel, kelompok II tabung berisi $10 \mathrm{ml}$ media Lactose Broth ditambah $1 \mathrm{ml}$ sampel, kelompok III tabung berisi $10 \mathrm{ml}$ media Lactose Broth ditambah 0,1 ml sampel. Selajutnya di inkubasi dengan suhu $37{ }^{\circ} \mathrm{C}$ selama $24-48$ jam. Kemudian di lihat tabung yang positif terdapat gas lalu di hitung tabung positif untuk setiap seri.

Uji penegasan (Comfirmative test) dilakukan apabila dari tabung yang menunjukkan uji praduga positif dipindahkan 1 jarum ose ke dalam tabung reaksi berisi $10 \mathrm{ml}$ Brillian Green Lactose Bile broth (BGLBB) yang telah dilengkapi tabung durham sesuai jumlah sampel awal (10 ml untuk 3 tabung pertama, $1 \mathrm{ml}$ untuk tabung kedua, dan $0,1 \mathrm{ml}$ untuk tabung ketiga). Selanjutnya seluruh tabung diinkubasi pada suhu $37^{\circ} \mathrm{C}$ selama $24-48$ jam. Dilakukan pengamatan adanya pembentukan gas (BPOM, 2006).

\section{HASIL DAN PEMBAHASAN}

\section{Angka Lempeng Total}

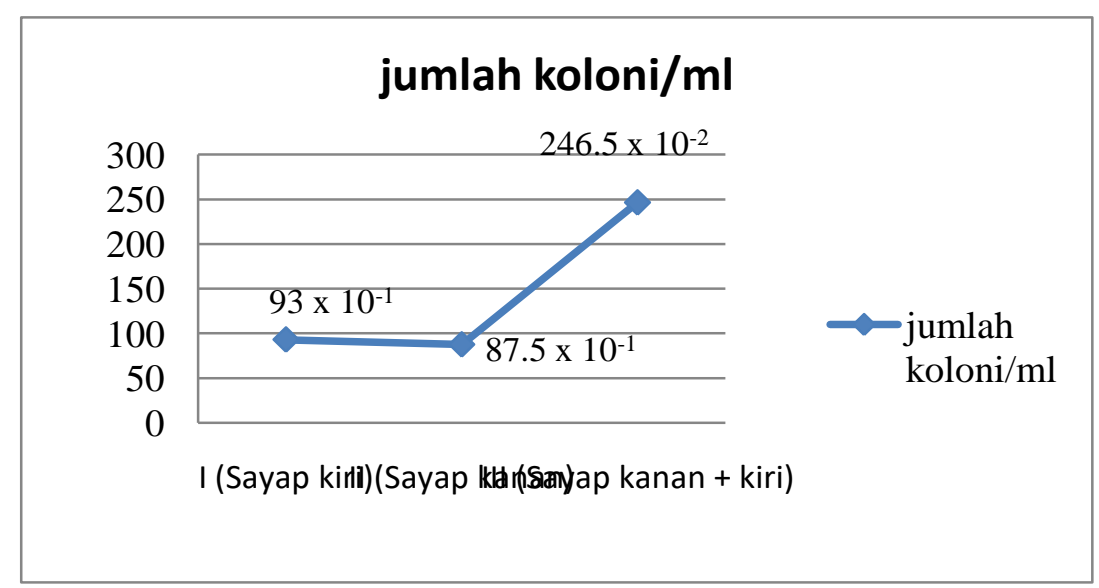

Gambar 1. Hasil Uji ALT berdasarkan standart deviasi

Hasil perhitungan sampel I dengan penambahan sayap kiri lalat rumah memiliki jumlah ALT $93 \times 10^{1}$ koloni/ml, Sampel II dengan penambahan sayap kanan lalat rumah memiliki jumlah 


\section{Jurnal MEDFARM: Farmasi dan Kesehatan}

Vol. 9, No.1, Januari 2020, hal 1-7

e-ISSN : 2715-9957

ALT 87,5 x 10 ${ }^{1}$, Sampel III dengan penambahan sayap kanan dan kiri memiliki jumlah ALT 246,5 x $10^{2}$ koloni/ml. Nilai ALT pada setiap sampel tersebut menunjukkan jumlah bakteri aerob mesofil yang terdapat pada masing-masing sayap lalat rumah (Musca Domestica).

Sedangkan adanya perbedaan jumlah ALT pada sampel membuktikan bahwa pada setiap sayap kiri, sayap kanan dan sayap kanan kiri yang terdapat pada lalat rumah (Musca Domestica) masingmasing memiliki jumlah bakteri yang berbeda. Sumber mikroba dapat berasal dari sampel, praktikan, air yang digunakan, alat yang digunakan, serta proses pemanasan yang tidak sesuai dengan suhunya.

\section{Uji Kapang Khamir}

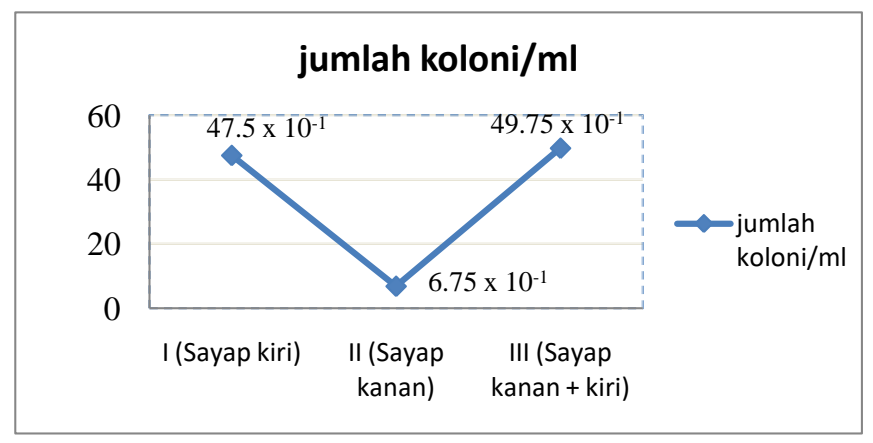

Gambar 2. Hasil Uji AKK berdasarkan standart deviasi

Hasil perhitungan sampel I dengan penambahan sayap kiri lalat rumah memiliki jumlah AKK $47,5 \times 10^{-1} \mathrm{koloni} / \mathrm{ml}$, Sampel II dengan penambahan sayap kanan lalat rumah memiliki jumlah AKK $6,75 \times 10^{-1} \mathrm{koloni} / \mathrm{ml}$, dan Sampel III dengan penambahan sayap kanan dan kiri lalat rumah memiliki jumlah AKK 49,75 x 10 $10^{-1} \mathrm{koloni} / \mathrm{ml}$.

Nilai AKK pada setiap sampel tersebut menunjukkan bahwa pada setiap sayap lalat rumah selain mengandung bakteri juga menunjukkan adanya pertumbuhan jamur. Sedangkan adanya perbedaan jumlah ALT pada sampel membuktikan bahwa pada setiap sayap kiri, sayap kanan dan sayap kanan kiri yang terdapat pada lalat rumah (Musca Domestica) masing-masing memiliki jumlah bakteri yang berbeda. Berdasarkan penelitian yang telah dilakukan oleh parveen (2014) adanya kapang khamir dapat berasal dari sampel dan pada saat proses analisa.

\section{Uji Most Probable Number (MPN) Coliform}

Tabel 1. Hasil uji Most Probable Number (MPN) Coliform

\section{Data Hasil Uji MPN}

\begin{tabular}{ccccc}
\hline Sampel & $\begin{array}{c}\text { Sampel }+ \\
\mathbf{1 0} \mathbf{~ m l}\end{array}$ & $\begin{array}{c}\text { Sampel + 1 } \\
\mathbf{m l}\end{array}$ & Sampel + 0,1 ml & Jumlah MPN/100 ml \\
\hline 1 & 3 tabung $(+)$ & 3 tabung $(+)$ & 3 tabung $(+)$ & $>2400$ MPN/100 ml \\
2 & 3 tabung $(+)$ & 3 tabung $(+)$ & 3 tabung $(+)$ & $>2400$ MPN/100 ml
\end{tabular}




\section{Jurnal MEDFARM: Farmasi dan Kesehatan}

Vol. 9, No.1, Januari 2020, hal 1-7

e-ISSN : 2715-9957

$$
3 \quad 3 \text { tabung }(+) \quad 3 \text { tabung }(+) \quad 3 \text { tabung }(+) \quad>2400 \mathrm{MPN} / 100 \mathrm{ml}
$$

Hasil pengujian dan perhitungan pada setiap sampel aquadest steril yang telah ditambahkan sayap lalat rumah memiliki hasil uji MPN Coliform sebagai berikut. Pada sampel I (Sayap kiri), >2400 MPN/100ml, sampel II (Sayap kanan), >2400 MPN/100ml, Sampel III (Sayap kanan kiri), $>2400 \mathrm{MPN} / 100 \mathrm{ml}$.

Nilai MPN Coliform pada setiap sampel menunjukkan bahwa pada setiap sayap lalat rumah terdapat bakteri Coliform. Adanya bakteri Coliform pada makanan/minuman menunjukkan kemungkinan adanya mikroba yang bersifat enteropatogenik dan toksigenik yang berbahaya bagi kesehatan. Sehingga apabila suatu makanan atau minuman yang tercemar oleh bakteri tersebut maka makanan atau minuman tersebut tidak layak untuk di konsumsi.

\section{KESIMPULAN DAN SARAN}

\section{Kesimpulan}

Hasil penelitian menunjukkan bahwa aquadest steril yang telah ditambahkan sayap kanan lalat rumah, mempunyai nilai ALT dan AKK yang lebih rendah dibandingkan dengan aquadest steril yang telah ditambahkan sayap kiri lalat rumah dan aquadest steril yang telah ditambahkan sayap kanan dan kiri lalat rumah. Hasil uji MPN Coliform ketiga sampel teridentifikasi mengandung bakteri Coliform yang melebihi batas yang telah ditetapkan. Berdasarkan hadist Al-Bukhary Muslim No. 3073 di jelaskan apabila suatu makanan atau minuman ditambahkan kedua sayap lalat rumah maka salah satu sayapnya dapat digunakan sebagai penawar penyakit. Namun dari hasil penelitian di dapatkan hasil bahwa ketika aquadest steril ditambahkan kedua sayap lalat rumah memiliki jumlah nilai ALT, AKK, dan MPN Coliform yang tinggi. Sehingga apabila suatu makanan atau minuman yang telah kemasukkan lalat maka minuman tersebut tidak dapat di konsumsi.

\section{Saran}

Perlu dilakukan kembali uji terhadap masing-masing sampel untuk mengetahui jenis bakteri dan jamur apa yang tumbuh pada sayap kanan maupun sayap kiri lalat rumah (Musca Domestica) sehingga dapat mempengaruhi perbedaan jumlah pertumbuhan mikroba.

\section{DAFTAR PUSTAKA}

Badan Pengawas Obat Dan Makanan Republik Indonesia. 2006. Metode Analisis Microbiologi. Pusat Pengujian Obat dan Makanan Badan Pengawasan Obat dan Makanan Republik Indonesia: Jakarta.

Badan Pengawas Obat Dan Makanan Republik Indonesia. 2008. Pengujian Mikrobiologi Pangan. Info POM Vol. 9, No. 2, Maret 2008. Jakarta: Badan Pengawas Obat Dan Makanan.

Fardiaz, Dedi, 2002. Panduan Pengolahan Pangan yang Baik bagi Industri Rumah Tangga, Jakarta: Badan Pengawas Obat dan Makanan. 
Jurnal MEDFARM: Farmasi dan Kesehatan

Vol. 9, No.1, Januari 2020, hal 1-7

e-ISSN : 2715-9957

Isnayanti. 2014. Hadist tentang "Mencelupkan" Lalat dalam Minuman (Suatu Kajian Tahli>li> dengan Analisis Kesehatan). (Skripsi) Ilmu Hadis. Fakultas Ushuluddin dan Filsafat.

Lay. 1994. Analisis Mikroba Di Laboratorium. Jakarta: PT.Raja Gravindo Persada

Parveen.dkk. 2014. Microbiological quality assessment of three selected spices in Bangladesh. International Food Research Journal.

Safitri, V. Hastutiek, P., Arimbi. 2017. Identifikasi Bakteri pada Eksoskeleton Lalat di Beberapa Pasar di Surabaya Identification of Bacteria on the Fly Exoskeleton in Some Markets inSurabaya. Journal of Parasite Science. 1 (1):1-6.

Standar Nasional Indonesia. 2009. Batas Maksimum Cemaran Mikroba Dalam Pangan. Nomor 73882009. Bogor: Badan Standarisasi Nasional Indonesia. 